\title{
Excel for Accounting Assistance as the Solution for SME PT. JAB Surabaya
}

\author{
Titis Puspitaningrum Dewi Kartika, Nosy Yodi Metana, Sri Lestari Kurniawati \\ STIE Perbanas Surabaya \\ Titis puspita@perbanas.ac.id
}

\begin{abstract}
Several studies suggested that most of Small and Medium Enterprises (SMEs) only noted the amount of money received and expended, the amount of bought and sold goods, and the amount of accounts receivable/debt. However, the note is functioned as reminder but not supported with the format desired by the banks. Even though, they are still able to know the amount of final capital each year which is almost the same as if we took a note by using accounting system. Therefore, Small and Medium Enterprises (SMEs) are directed through assistance to start taking notes of its business activities in accordance with the Accounting Standards Entities of Micro, Small and Medium Enterprises (SAK EMKM) simply and completely as needed. Basically, the partner's problem in this assistance was due to the accounting administration of financial management at PT. JAB which is not properly arranged such as the determination of HPP. This SME produces coffee powder, chocolate and green tea beverages. It reaches income of Rp. 50.000.000,- per month with the total 3-5 employees and has carried out bookkeeping which is currently experiencing loss. It has already made an excel financial report but in determining HPP, the process costs are not taken into account so that this has no basis. The result of this assistance is the establishment of financial statement which is correct and appropriate in accordance with SAK EMKM. This study is finally able to solve the problem in determining the amount of HPP due to the lack of synchronization between the production data and accounting department. In addition, this study successfully minimizes errors in determining the amount of inventory which affects the error in determining HPP. The problem faced by every SME must be different so that we are expected to provide assistance in making financial reports.
\end{abstract}

Keywords: Excel for accounting assistances, SAK EMKM

\begin{tabular}{|c|c|c|}
\hline Received & Revised & Published \\
\hline 7 January 2019 & 12 February 2019 & 30 March 2019 \\
\hline
\end{tabular}




\section{INTRODUCTION}

Micro, Small, and Medium Enterprises (MSMEs) are still being the economic main support of Indonesia nowadays. The rapid development of MSMEs indicates that the investment climate continues to grow so that it attracts many investors to invest. One of the business centers of East Java, namely Surabaya, has a very large amount of investment turnover which is influenced by the MSMEs' investment. A large contribution from MSMEs encourages the government to improve the economic matters. Government support through various MSME empowerment programs has a positive impact on the growth of MSMEs. According to data from Department of Cooperatives and Small-Medium Enterprises of East Java Province, the number of MSMEs in Surabaya was 260.762. MSMEs in Surabaya could provide employment for 466.779 people. The amount of employment is expected to overcome the limited opportunities of finding a job.

An enterprise (entity) can be categorized as a micro, small, or medium as indicated by the number of assets owned and/or the amount of revenue produced. Along with the improving number of MSMEs, it will also increase business competition as well. Various problems are faced by MSMEs in their business activities, such as capital and marketing matters. Innovation, product differentiation, and loan credit can be organized by MSMEs. The additional capital through loan credit is a solution for MSMEs to make it easier to expand the type of business, enlarge the amount of production, and expand the number of employees in line with increasing market demand. They could be useful to overcome the tough competition and problems faced by MSMEs.

According to the Law of the Republic of Indonesia No. 20 of 2008 concerning Micro, Small and Medium Enterprises, it explains that Micro Enterprises shall be productive businesses owned by individual persons and/or individual business entities that meet the criteria of Micro Enterprises as provided for herein. Small Enterprises shall be productive economic businesses standing alone, done by individual persons or business entities not constituting subsidiaries or not constituting company branches owned, controlled, or becoming direct or indirect portions of Medium or Large Enterprises that meet the criteria of Small Enterprises as intended herein. Moreover, Medium or Large Enterprises shall be productive economic businesses standing alone, done by individual persons or business entities not constituting subsidiaries or not constituting company branches owned, controlled, or becoming direct or indirect portions of Small or Large Enterprises with the amount of net assets or annual sales proceeds as provided for herein. Small and medium enterprises are classified as home-based industry, so they tend to have a relatively short business time. Financial Accounting Standards in Indonesia are regulated by the Financial Accounting Standards Board of the Institute of Indonesia Chartered Accountants (DSAK IAI). For micro, small and medium enterprises, the financial reports produced are simpler than those of well-known companies, and the standards used are Micro, Small and Medium Financial Accounting Standards (SAK EMKM).

SAK EMKM is designing to encourage and facilitate micro, small and medium enterprises in proposing financial reports. This standard is used by entities which do not have significant public 


\section{THE SPIRIT OF SOCIETY JOURNAL}

International Joumal of Society Development and Engagement

ISSN : 2597-4777 (Online) - ISSN : 2597-4742 (Print)

This work is licensed under a Creative Commons Attrib ution-ShareAlike 4.0 International License.

accountability and fulfill the definition and criteria of MSMEs according to Law No. 20 of 2008. The criteria are as followed: (a) not constituting subsidiaries or not constituting company branches owned, controlled, or becoming direct or indirect portions of Medium or Large Enterprises; (b) quantitative range consists of: (i) micro enterprises, having maximum net assets of Rp. 50.000 .000 and having maximum revenue of $\mathrm{Rp}$. 300.000.000; (ii) small enterprises having maximum net assets from Rp. 50.000 .000 up to Rp. 500.000 .000 and having maximum revenue from Rp. 300.000.000 up to Rp. 2.500.000.000 (iii) medium enterprises, having net assets from Rp.500.000.000 up to Rp. 10.000.000.000, and having revenue of Rp.2.500.000.000 up to Rp.50.000.000.000; and (c) do not own and or control the MSMEs of their business partners. In addition, for newly established entities, at least 2 consecutive years are in the form of MSMEs.

This SAK EMKM financial reporting framework is expected to assist entities in transitioning financial reporting on a cash basis to financial reporting on an accrual basis. The publication of the SAK EMKM is expected to be one of the financial literacy supports for MSMEs in Indonesia in order to gain broader access for financing the banking industry. In the future, this SAK EMKM is also expected to be a basic guideline for the arrangement and development of accounting for MSMEs engaged in various business fields. This SAK EMKM will be effective by January $1^{\text {st }} 2018$ with early application permitted. SAK EMKM will be officially launched at the momentum of Institute of Indonesia Chartered Accountants (IAI) anniversary commemoration held on 8 - 9 December 2016 in Bandung, West Java. The launch of SAK EMKM become one of the important agenda at the event since it is an offering from IICA which is expected to provide the benefit for Indonesian development.

Data of registered entrepreneur in East Java SMEs consists of several cities and regions: Madura region particularly Bangkalan has 3 SMEs, Pamekasan 97 SMEs, Sampang 30 SMEs, and Sumenep 4 SMEs. For Batu region, there are 19 SMEs; Malang 58 SMEs, Blitar 98 SMEs, Bojonegoro 7 SMEs, Bondowoso and Ngawi only 1 SME of each. Furthermore, Gresik has 110 SMEs, Jember 88 SMEs, and the highest registered SMEs is in Jombang with 190 SMEs. Moreover, Kediri has 11 SMEs, Lamongan 78 SMEs, Lumajang and Pacitan only has 8 SMEs for each, Madiun has 78 SMEs, Magetan 26 SMEs, Mojokerto 39 SMEs, Pasuruan 16 SMEs, while in Probolinggo, either the city or rural areas has 98 SMEs (www.forum-ikmjatim.com)

The problems faced by the SMEs' partner are basically due to the lack of information on the importance of bookkeeping administration and the lack of updated accounting knowledge in financial management. SMEs can use SAK EMKM as a reference in making financial reports. Partners who will be accompanied are community groups that are economically productive (microenterprises) that is involved in SMEs in East Java. The partner we chose was one of the SMEs in the Surabaya, namely Kopi D'Lanang owned by Mr. Achmad Nur Syamsul Hidayat. Kopi D'lanang has monthly revenue more than Rp. 50.000 .000 so that it can be categorized as micro enterprise. This micro enterprise is suggested to apply SAK EMKM because it is simpler than Financial Accounting Standards for Non-Publicly-Accountable Entities (SAK ETAP) which seemed difficult to applied by SMEs' owner previously.

Based on observation with the manager of East Java's SME, Mr. Nur who is the representation of Surabaya's SME, showed that his SME has made his own bookkeeping and 


\section{THE SPIRIT OF SOCIETY JOURNAL}

International Joumal of Society Development and Engagement

ISSN : 2597-4777 (Online) - ISSN : 2597-4742 (Print)

This work is licensed under a Creative Commons Attrib ution-ShareAlike 4.0 International License.

financial reports. Mr. Nur's SME is engaged in making coffee from processing raw materials into semi-finished goods and selling semi-finished goods, processing semi-finished goods into finished goods and selling them in the form of coffee powder and reprocessing them into liquid coffee / ready to drink. Going through these processes, Mr. Nur has the difficulty to determine the cost of goods sold in each product. Consequently, in determining coffee pricelist, he only estimated how much margin that he will obtain. In addition to cost of goods sold, Mr. Nur's SME also used financial reports in order to pay taxes but still use the services of others to do so.

\section{LITERATURE REVIEW Definition of SME}

Some limitations regarding the MSMEs scale are as follows:

1. Based on Law No. 20 of 2008:

a. The criteria of Micro Enterprises: having maximum net assets of Rp. 50,000,000.00, exclusive of land and building of their place of business; or having maximum annual sales proceeds of Rp. 300,000,000.00.

b. The criteria of Small Enterprises: having net assets of more than Rp. 50,000,000.00 up to a maximum amount of Rp. 500,000,000.00, exclusive of land and building of their place of business; or having annual sales proceeds of more than Rp. 300,000,000.00 up to Rp. 2,500,000,000.00.

c. The criteria of Medium Enterprises: having net assets of more than Rp. 500,000,000.00 up to Rp. 10,000,000,000.00, exclusive of land and building of their place of business; or having maximum annual sales proceeds of more than Rp. 2,500,000,000.00 up to Rp. $50,000,000,000.00$.

2. Based on Central Bureau of Statistics (BPS):

Micro : employees $<5$ persons including unpaid family employees

Small : : 5-19 employees

Medium: employees from 20 to 99 persons

3. Based on Government Regulation No. 46 of 2013:

Micro, Small, and Medium Enterprises has gross turnover does not exceed Rp. $4,800,000,000.00$ in one tax year.

East Java Local Government especially Surabaya has been providing guidance for SMEs. One of them is the Technical Service Unit (UPT) for the Development of Labor Productivity (PPTK) which is under the auspices of the Department of Manpower, Transmigration, and Population of East Java Province and is known by UPT. East Java PPTK reported at least there are 50 fostered SMEs in Surabaya area.

Here are some data related to 50 East Java SMEs fostered by PPTK in Surabaya:

1. Data of Education Level and enterprise age. 


\section{THE SPIRIT OF SOCIETY JOURNAL}

International Joumal of Society Development and Engagement

ISSN : 2597-4777 (Online) - ISSN : 2597-4742 (Print)

This work is licensed under a Creative Commons Attrib ution-ShareAlike 4.0 International License.

Table 1.1

\begin{tabular}{|l|c|c|c|}
\hline \multicolumn{1}{|c|}{ Profile } & N & Minimum & Maximum \\
\hline $\begin{array}{l}\text { Educational level (Elementary } \\
\text { up to Bachelor Degree) }\end{array}$ & 47 & 6 & 16 \\
\hline Enterprises age (year) & 47 & 1 & 25 \\
\hline
\end{tabular}

Source: Fransiska 2016

From 47 SMEs, the average of educational level of the owners is secondary level (primary level: 6 persons and tertiary level: 16 persons), while the average of enterprises age is 5.26 years (minimum: 1 year and maximum 25 years).

2. Enterprises Revenue Data.

Table 1.2 Enterprises Revenue Data

\begin{tabular}{|l|r|r|}
\hline \multicolumn{1}{|c|}{ Scale } & Frequency & Percent \\
\hline Less than Rp. 25.000.000,- & 39 & 83.0 \\
\hline Rp. 25.000.000,- up to Rp. 75.000.000 & 7 & 14.9 \\
\hline More than Rp. 75.000.000,- & 1 & 2.1 \\
\hline Total & 47 & 100.0 \\
\hline
\end{tabular}

Source: Fransiska 2016

Table 4.2 shows that there are 39 SMEs which have maximum revenue $25,000,000$,- or around $83 \%$ of the total. Moreover, there are 7 SMEs which have revenue from Rp. 25.000.000,up to Rp. 75.000 .000 ,- or around $14.9 \%$. For the revenue which is more than Rp. 75.000.000,-, there is only one enterprise or $2.1 \%$ from the total SMEs.

3. Enterprises Scale Data

\section{Table 1.3 Enterprises Scale Data}

\begin{tabular}{|c|c|c|}
\hline Data & Frequency & Percent \\
\hline Micro (employees < 5 persons) & 35 & 74.5 \\
\hline Small (employees 5-19 persons) & 11 & 23.4 \\
\hline Medium & 1 & 2.1 \\
\hline Total & 47 & 100.0 \\
\hline
\end{tabular}

Source: Fransisca 2016

Table 4.3 shows that the largest scale of business is in micro-enterprises (35 companies) or around $74.5 \%$. This means that most companies that become the sample of this study have employees who are less than 5 people. In addition, the data shows that there are 11 small enterprises (23.4\%) with 5-19 employees. Furthermore, there is only one medium-sized enterprise $(2.1 \%)$ that has $20-99$ employees. 
4. Data of Training and Application of Accounting Information

Table 1.4 Data of Training and Application of Accounting Information

\begin{tabular}{|l|c|c|c|c|}
\hline Profile & N & Min. & Max. & Mean \\
\hline Accounting training & 47 & 2 & 5 & 3.40 \\
\hline $\begin{array}{l}\text { Application of Accounting } \\
\text { Information }\end{array}$ & 47 & 1 & 5 & 3.390 \\
\hline
\end{tabular}

Source : Fransiska 2016

Table 4.4 shows the data of training and application of accounting information. It can be seen from the table that accounting training which has been attended by the manager/owner of enterprises is only twice for minimum and five times of the most. Meanwhile, it can be inferred also that there is still a lack of application of accounting information carried out by each enterprise.

\section{Financial Report}

Financial report is the result of accounting process which provides financial information of a company that is beneficial for parties involved in economy decision making (Isnawan: 2012:60). The purpose of financial report according to SAK EMKM 2016 is to provide the information of financial position and entity performance which is beneficial for mostly users in economic decision making by anyone who is not in a position to be able to request specific financial reports to meet the information needed. The users involve resource provider for entity such as creditor or investor. In achieving the purposes, financial reports also indicate management's responsibility of any resources entrusted to it. The purpose of financial statements according to Irham (2012: 24):

1. Providing information to parties who need about the condition of a company in terms of numbers in monetary units.

2. Providing information that is useful for business and economic decision makers by existed and professional investors, creditors, management, government and other users.

3. Providing information regarding financial position, performance and changes in the financial position of a company that is beneficial for most users in economic decision making.

4. Providing information about financial position, changes performance of equity, cash flow and other information.

\section{SAK EMKM}

The following are the contents of Micro, Small and Medium Financial Accounting Standards:

\section{The Users:}

The company of which exists more than two years in a row based on laws.

\section{Financial position report}




\section{THE SPIRIT OF SOCIETY JOURNAL}

International Joumal of Society Development and Engagement

ISSN : 2597-4777 (Online) - ISSN : 2597-4742 (Print)

This work is licensed under a Creative Commons Attrib ution- ShareAlike 4.0 International License.

\section{The components:}

1. Assets; owned resources, the past, contained economic benefits.

2. Liabilities; current obligations, past, resulting in cash out, economic benefits.

3. Equity is residual rights to assets after deducting liabilities.

\section{Performance}

The components:

1. Income; increase in economic benefits, cash inflows/ increase in assets/liabilities, not capital.

2. Expense; decrease in economic benefits, cash out / decrease in assets / liabilities, not capital.

The basis for measuring the component of financial reports in SAK EMKM is historical costs.

The reporting frequency is in the end of each period, including min 2 years of comparative information.

\section{Components of entity financial reports:}

1. Financial position reports in the end of period

2. Income statement for the period

3. Notes of financial reports consisting of additional and detailed specific posts

\section{Entity financial report items:}

1. Cash and cash equivalent

2. Debt

3. Stock

4. Fixed assets

5. Account receivables

6. Bank loan

7. Equities

\section{Entity income statement items:}

1. Income

2. Financial expenses

3. Tax expenses

\section{Record items of the entity's financial reports:}

1. A financial report is composed based on SAK EMKM

2. Accounting policy overview

3. Additional information and specific post details

\section{Recording methods:}




\section{THE SPIRIT OF SOCIETY JOURNAL}

International Joumal of Society Development and Engagement

ISSN : 2597-4777 (Online) - ISSN : 2597-4742 (Print)

This work is licensed under a Creative Commons Attrib ution- ShareAlike 4.0 International License.

1. Assets and financial liabilities

- Recognition and measurement; Cost is measured at the transactional price.

- At the end of reporting; assets and financial liability is measured at the transactional price and reduced by principal and interest payment.

- The entity does not recognize the value declining of financial assets.

\section{Stocks}

-recognition and measurement; including purchase cost, conversion, and others.

* techniques for measuring inventory costs such as standard or retail costs.

* able to utilize FIFO or Average

- Inventories damaged or obsolete are considered as expenses

\section{Investment in joint ventures}

-recognition and measurement; measures at the income costs

* The entity does not recognize a decline of the investment value

\section{Fixed assets}

-Recognition and measurement; including purchase price and costs that are directly attributable.

-Repair and maintenance costs are recognized in the income statement.

-Depreciation using the straight-line method and the declining balance method, with no residual value.

* The entity does not recognize the value decline of fixed assets.

\section{Intangible assets}

- Recognition and measurement; including purchase price and costs that are directly attributable.

- The age of intangible assets has limited benefits

- Amortization starts when the asset is ready to use.

- Amortization uses the straight-line method and declining balance, without residual value.

- Intangible assets produced by the internal are considered as expenses when incurred.

${ }^{*}$ For example: research and development activities, brands, pioneering, training and advertising

* the entity does not admit the value decline of intangible assets

\section{Liability and equity}

- Recognition and measurement; recorded at the amount to be paid.

- The entity does not recognize contingent provisions and liabilities.

- Paid up capital can be in the form of cash / cash equivalent / non-cash assets in accordance with the law. 


\section{THE SPIRIT OF SOCIETY JOURNAL}

International Joumal of Society Development and Engagement

ISSN : 2597-4777 (Online) - ISSN : 2597-4742 (Print)

This work is licensed under a Creative Commons Attrib ution- ShareAlike 4.0 International License.

- profit balance represent the difference of income and expenses minus distribution to owners.

\section{Income and Expenses}

- Income; when there is a right of payment either received or must be received.

- Income and contract costs are recognized as the amount of the bill.

- Rental income and royalties are recognized using the straight line method during the contract.

- Grant income is recognized in profit or loss except part of the owner's contribution.

\section{Income tax}

- Recognition and measurement; following the applicable tax laws.

- Entity does not recognize deferred tax assets

\section{Transactions in foreign currencies}

- The entity records transactions in rupiah based on the exchange rate of the transaction date.

\section{METHOD}

This activity was carried out at PT. Jarkom Artha Barokah which is engaged in a manufacturing company located in Semampir Selatan VA Surabaya from January to August 2018. This study used qualitative method. Type and source of data was obtained by primary data from SME by interviewing, documentation, and observation. The data was further analyzed by using interactive analysis model which consists of three components which are data reduction, data presentation, and conclusion or verification.

\section{RESULT AND DISCUSSION}

\section{An overview of PT Jokam Artha Barokah}

PT Jokam Artha Barokah, hereinafter referred as PT. JAB, is a manufacturing company engaged in coffee which is located at Semampir Selatan VA-18 Surabaya or could be visited at https://jokamarthabarokah.indonetwork.co.id/. PT. JAB is a branch company of PT. Shelter Indonesia engaged in outsourcing. PT. Shelter itself is included into the medium-sized companies so that the management owned has been running in accordance with the SOP that has been made, hence, this has an impact on the branch company. The management of PT. JAB could be said to have good administration. It was proven in managing finances that have been properly administered, they already have computerized financial reporting. Even though the financial statements have not referred to the applicable financial standards yet, it has been already good enough for this micro SME category to have financial reports.

$\mathrm{PT}$. JAB is a manufacturing company engaged in coffee making; starting from processing coffee into ground coffee, ready-to-drink coffee and in the future will be formulated again for liquid coffee. Coffee sales include coffee beans, ground coffee, packaged coffee with the D'Lanang brand. The coffee produced comes from coffee farmers in Jember. The coffee production was carried out in Jember and Surabaya at first. However, in 2017, coffee production has begun to 


\section{THE SPIRIT OF SOCIETY JOURNAL}

International Joumal of Society Development and Engagement

ISSN : 2597-4777 (Online) - ISSN : 2597-4742 (Print)

This work is licensed under a Creative Commons Attrib ution-ShareAlike 4.0 International License.

operate in Surabaya. Besides coffee, PT. JAB also sells chocolate (powder) beverage with D'Kraton and D'Lima brand for teabag. The following are the figures of coffee and chocolate in packaging:

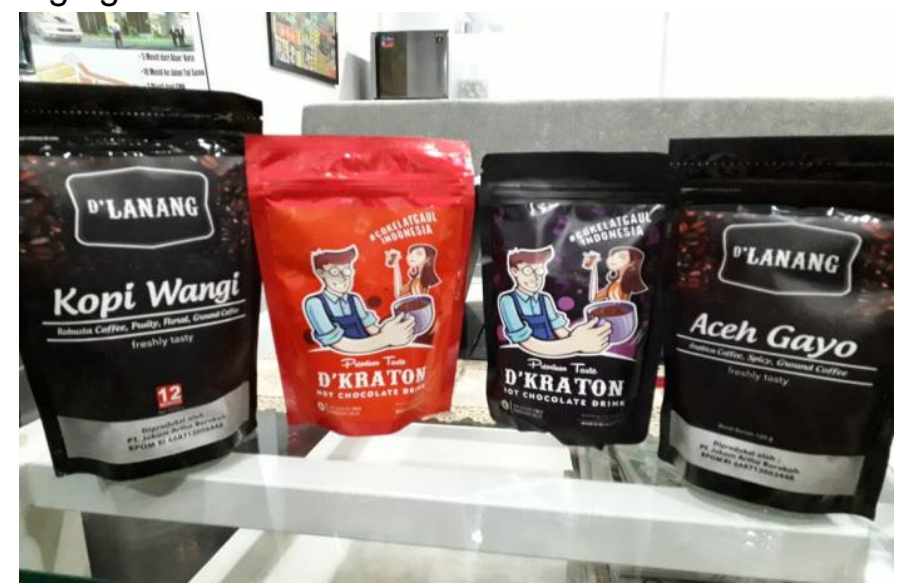

Figure 4.1 Coffee and chocolate package

Based on the interview with the marketing, it was said that the products of PT. JAB are selected and processed from high quality raw materials. The products also have unique and delicious taste. The superior product of PT. JAB is Jinten (cumin) coffee, which is the selected ground coffee made with a mixture of cumin (black seed) and cardamom as well as selected ginger roots originating from Arab. This superior product has an exotic taste and presents many health benefits, especially increasing vitality and stamina.

The coffee of PT. JAB production has three variances: D'lanang Jinten Coffee Rp. 28.000,-, D'Lanang Robusta Coffee Rp. 18.000,- and D'Lanang Arabica Coffee Rp. 24.000,- per package. Chocolate powder drink has two flavor variances, namely D'Kraton Dark Chocolate and D'Kraton Light (Low fat) with prices of Rp. 30.000,- per package. For the third product, tea, it also has three variances at a price of Rp. 15.000 per package.

\section{Jokam Artha Barokah Financial Report}

PT. JAB financial report has been computerized by using excel which is integrated with production section. Based on the established standard, this company has made financial position reports, profit / loss reports, cash flow reports, inventory reports, debt reports, general ledger reports, and income statements.

The followings are examples of report made by PT. JAB:

\section{Financial position report}

Excel for Accounting Assistance as the Solution for SME PT. JAB Surabaya 


\section{THE SPIRIT OF SOCIETY JOURNAL}

International Joumal of Society Development and Engagement

ISSN : 2597-4777 (Online) - ISSN : 2597-4742 (Print)

This work is licensed under a Creative Commons Attrib ution-ShareAlike 4.0 International License.

According to SAK EMKM (2016), financial position report provides assets, liability, and equity of entity at the end of certain periods. The financial position report includes posts in accordance with the applicable standards namely cash and cash equivalent, debt, inventories, fixed assets, receivable account, and bank loans. The followings are the financial position report made by SME of PT. JAB Surabaya:

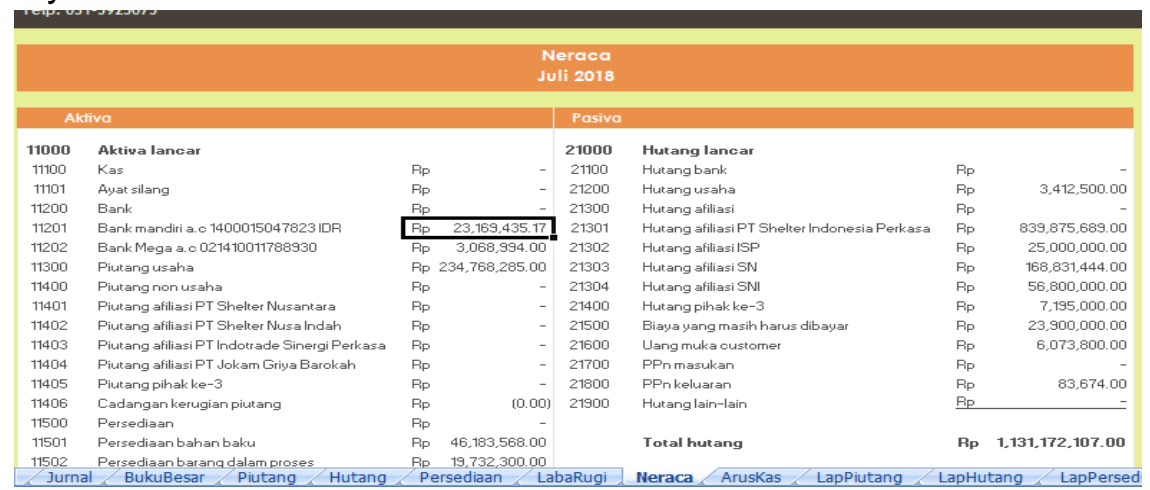

Figure 4.2 Financial Position Report of PT. JAB

Information:

1. PT. JAB presents assets and liabilities in one financial position report.

2. PT. JAB classifies as current assets when owned for trading, in the form of cash and cash equivalent

3. PT. JAB classifies short-term liabilities when it is expected to be completed within 12 months after the end of reporting period.

4. There are several accounts misclassified.

\section{Profit/Loss Reports}

A profit / loss reports provide information about income, financial expense, tax expense (SAK EMKM, 2016). SAK EMKM regulated the correction effects of errors and the changes in accounting policies which are conveyed as retrospective adjustment in past and they are not the part of profit/loss incurred. The following is the explanation of profit/loss report in SME PT. JAB:

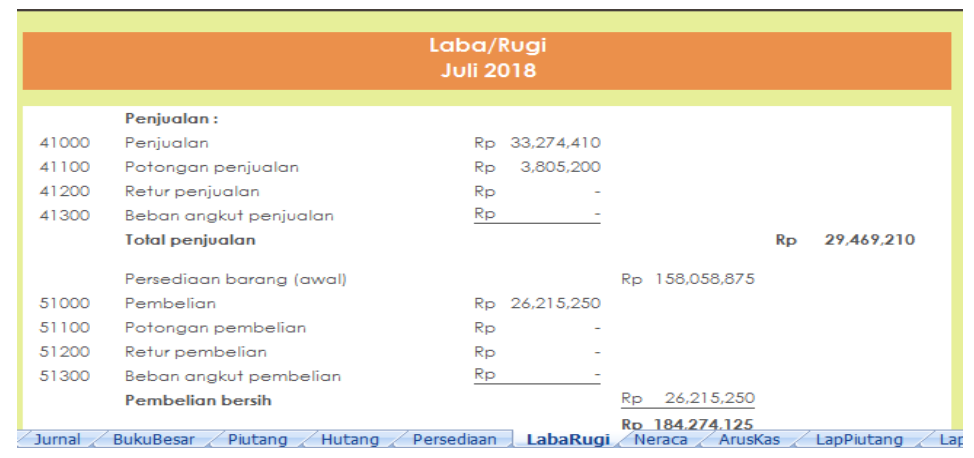

Figure 4.2. Profit/Loss report of PT. JAB

Excel for Accounting Assistance as the Solution for SME PT. JAB Surabaya 


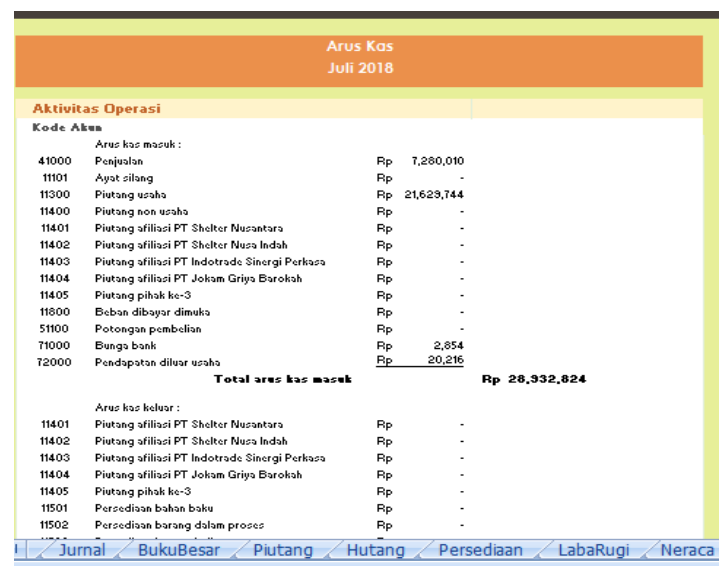

Figure 4.4 Cash flow report

\section{Information:}

1. PT. JAB includes all income and expenses in one period

2. Profit/Loss report of PT. JAB consists of income, financial expense, and tax expense

3. There are several accounts misclassified.

The calculation of cost of goods sold (HPP) in PT. JAB still has to be adjusted to the posts used and clearly classified based on consumables materials, semi-finished materials, and overhead costs. Consequently, there are a lot of costs which have to be clearly defined based on their used. As the result, the mismatch of data between production department and financial department might happen. Interpretation of account costs will make both divisions have different opinion.

\section{Note to Financial reports}

PT. JAB only has simple information of financial report notes, not the detailed one. The note governs the principles underlying the information presented and how it is presented. The notes to financial reports must contain a statement that financial report has been designed based on SAK EMKM. There must be an overview of accounting policies, additional information and detail of certain posts that explains important transactions and material in order to be useful for users to understand financial report. The type of additional information should be based on the activities carried out by PT. JAB and the reports must be systematically and practically presented.

\section{CONCLUSION}

PT. Jokam Artha Barokah (PT. JAB) is a company which deals with coffee manufacturing. It is located in Semampir Selatan VA- 18 Surabaya with the website 


\section{THE SPIRIT OF SOCIETY JOURNAL}

International Joumal of Society Development and Engagement

ISSN : 2597-4777 (Online) - ISSN : 2597-4742 (Print)

This work is licensed under a Creative Commons Attrib ution-ShareAlike 4.0 International License.

https://jokamarthabarokah.indonetwork.co.id/. PT. JAB is a branch company of PT. Shelter Indonesia engaged in outsourcing matters. PT. JAB processes coffee from raw material to ground coffee, ready-to-drink coffee, and going forward, this company will create liquid coffee. Coffee sales include coffee beans, ground coffee, and packaged coffee with the D'Lanang brand. The coffee produced from farmers in the Jember area. The coffee was sold in Jember and Surabaya at first. However, in 2017, coffee production has begun to operate in Surabaya. Besides coffee, PT. JAB also sells chocolate (powder) beverage with D'Kraton and D'Lima brand for teabag. Overall, financial report of PT. JAB has already appropriate with SAK EMKM which includes financial position and profit/loss report. However, the note to financial reports have not been systematically and practically presented. PT. JAB has provided assets and liabilities in one financial position report. It has classified as current assets when owned for trading, in the form of cash and cash equivalent. In addition, PT. JAB has classified short-term liabilities when it is expected to be completed within 12 months after the end of reporting period. Profit/loss report of PT. JAB has included all earnings and expenses in one period. It involved incomes, financial expenses, and tax expenses. Related to the calculation of (HPP), PT. JAB still has to be adjusted to the concept of production department and financial department so that it does not cause the misperception that makes the HPP determination still needs to be revised. This might happen because of frequent changes in the production division so that the reports presented are different. Besides, PT. JAB still does not have a specific standard regarded to preparing report for production division.

\section{REFERENCE}

Agnur, Daniel. (2009). Penyusunan Decission Support System (DSS) Study Kelayakan Ekonomi dan Financial bagi UKM. Jurnal Vol.4 Agustus 2009:1-17.

Ediraras, Dhama T. (2010). Akuntansi dan Kinerja UKM. Jurnal Ekonomi Bisnis,No.2 Vol.15.

Fransiska, Ade Julia. (2016). Pengaruh Tingkat Pendidikan, Umur Perusahaan, Omzet Usaha, Skala Usaha dan Pelatihan Akuntansi Terghadap penerapan Informasi Akuntansi Para Pelaku UKM. Skripsi STIE Perbanas Surabaya. Tidak Diterbitkan

Isnawan, ganjar. (2012). Akuntansi Praktis Untuk UMKM. Jakarta: Laskar Aksara

Narsa, I Made., Agus Widodo, dan Sigit Kurnianto. (2012). Mengungkap Kesiapan UMKM dalam Implementasi PSAK-ETAP Untuk Meningkatkan Akses Modal Perbankan. Majalah Ekonomi, Vol.3.2012.

Undang-Undang RI No. 28. 2008 Tentang Usaha Mikro, Kecil dan Menengah

Peraturan Pemerintah RI No. 46 tahun 2013 Tentang Pajak Penghasilan atas Penghasilan Dari Usaha Yang Diterima atau Diperoleh Wajib Pajak Yang Memiliki Peredaran Bruto Tertentu.

Rudiantoro, Rizki dan Sylvia Veronica Suregar. (2012). Kualitas Laporan KeuanganUMKM serta Prospek Implementasi SAK ETAP. Jurnal Akuntansi dan Keuanga Indonesia, Vo.9 No.1 Juni 2012. 


\section{THE SPIRIT OF SOCIETY JOURNAL}

International Joumal of Society Development and Engagement

ISSN : 2597-4777 (Online) - ISSN : 2597-4742 (Print)

This work is licensed under a Creative Commons Attrib ution-ShareAlike 4.0 International License.

Sariningtyas, Pratiwi., Tituk Diah W. (2011)Standar Akuntansi Keuangan Entitas Tanpa Akuntabilitas Publik Pada Usaha Kecil dan Menengah. JAKI Vo.1 No.1.

Yuniarta, Gede Adi. (2013). Persepsi Praktisi Akuntansi terhadap Kelayakan hasil Pengembangan Perangkat Simulasi AKuntansi untuk UKM Berbasis Multimedia. Jurnal Akuntansi Profesi, Vol3 No.1 Juni 2013.

.https://jatim.bps.go.id/

www.pptatk.jatim.com

www.pppm.perbanas.ac.id

www.forum-ikmjatim.com 